\title{
RIKEN NATURAL RADIOCARBON MEASUREMENTS VII
}

\author{
FUMIO YAMASAKI, CHIKAKO HAMADA, and TATSUJI HAMADA \\ Institute of Physical and Chemical Research (RIKEN) \\ Wako-shi, Saitama Pref., Japan
}

The $\mathrm{C}^{14}$ dates given below are continued from our previous list ( $\mathrm{R}$., 1970 , v. 12, p. 559-576), and results obtained mainly during 1970 are described. A 2.7 L stainless steel counter and a $3.3 \mathrm{~L}$ copper counter are used, yielding background counting rates of 5.5 and $8.5 \mathrm{cpm}$, respectively, when filled with dead $\mathrm{CO}_{2}$ at ca. $1.8 \mathrm{~atm}$. Dates have been calculated on the basis of the $\mathrm{C}^{14}$ half-life of $5568 \mathrm{yr}$ and $95 \%$ of NBS oxalic acid as modern standard.

\section{SAMPLE DESCRIPTIONS \\ I. GEOLOGIG SAMPLES}

\section{Futtsu series}

$$
\text { A. Japan }
$$

Sample from boring core obtained at various localities near Futtsucho, Kimitsu-gun, Chiba Pref. Coll. 1966 and subm. by K. Kojima, Public Works Research Inst., Ministry of Construction.

\section{N-749. Futtsu 1}

$2440 \pm 115$

490 B.C.

Shell fragments from muddy sand in sub-bottom core, -29.2 to 29.7 m, off Futtsu (35 $19^{\prime} \mathrm{N}$ Lat, $139^{\circ} 45^{\prime}$ E Long). Sample from base of sediments overlying Pleistocene sub-bottom topography.

\section{N-750. Futtsu 2}

Shell fragments from sand in core as above, -50.3 to $51.4 \mathrm{~m}$, from top of sediments filling submarine buried valley.

\section{N-751. Futtsu 3}

$$
12,600 \pm 270
$$

Decayed wood from clay in core as above, -67.4 to $68.6 \mathrm{~m}$, from near bottom of sediments filling submarine buried valley.

\section{N-752. Futtsu 4}

$12,800 \pm 450$ 10,850 в.c.

Humic substance from sandy clay in core as above, -74.85 to 77.35 $\mathrm{m}$, from near base of sediments filling submarine buried valley.

\section{N-777. Futtsu 5}

$2970 \pm 125$

Shell fragments from sand in core, -18.35 to $18.50 \mathrm{~m}$ at Daini Kaiho near Futtsu (35० $18^{\prime} \mathrm{N}$ Lat, $139^{\circ} 44^{\prime} \mathrm{E}$ Long). Deposit overlies diluvial formation at $-50 \mathrm{~m}$. 
N-778. Futtsu 6

2750 B.C.

Shell fragments from sand in core, -4.48 to $4.78 \mathrm{~m}$ at Futtsu Bar (35 $15^{\circ} \mathrm{N}$ Lat, $139^{\circ} 47^{\prime} \mathrm{E}$ Long). Sand overlies old wave-cut terrace at $-20 \mathrm{~m}$.

\section{N-779. Futtsu 7}

$5330 \pm 135$

3380 B.C.

Shell fragments in sand deposit from core, +5 m near Futtsu Lodge (35 $18^{\prime} \mathrm{N}$ Lat, $139^{\circ} 48^{\prime} \mathrm{E}$ Long). Deposit overlies old wave-cut terrace at depth $-20 \mathrm{~m}$.

\section{N-780. Kimitsu}

Wood in silty mudstone from $-17.50 \mathrm{~m}$ in diluvial strata beneath old wave-cut terrace, at Kimitsu-cho, Kimitsu-gun, Chiba Pref. (35 $21^{\prime}$ N Lat, $139^{\circ}$ 52' E Long). Coll. 1969 and subm. by K. Kojima.

N-790. Ukishima

$>\mathbf{3 7 , 8 0 0}$

Shell fragments (Ostrea sp.) from core in Pleistocene valley fill at $-.85 \mathrm{~m}, 4.5 \mathrm{~km}$ off Okishima-cho, Kawasaki City, Kanagawa Pref. (35 $30^{\prime} \mathrm{N}$ Lat, $139^{\circ} 50^{\prime} \mathrm{E}$ Long). Coll. 1967 and subm. by K. Kojima.

\section{Takaoka series}

Pieces of timber buried in bog sediments, Takaoka-Oyachi, Muremura, Kami-minochi-gun, Nagano Pref. (36 $45^{\prime} \mathrm{N}$ Lat, $138^{\circ} 10^{\prime} \mathrm{E}$ Long). Coll. 1969 and subm. by T. Ochiai, Agric. Engineering Research Sta.

N-804. Takaoka 1

$1010 \pm 100$

From depth $1.1 \mathrm{~m}$ in dark green clay overlain by loam.

N-805. Takaoka 2

From depth $1.4 \mathrm{~m}$.

N-806. Takaoka 3

From depth $1.58 \mathrm{~m}$.

N-807. Takaoka 4

From depth $1.13 \mathrm{~m}, 6.3 \mathrm{~m}$ apart from N-804 $\sim 6$.

$$
\text { B. Australia }
$$

A.D. 940

$$
1840 \pm 105
$$

$$
\text { A.D. } 110
$$

$3440 \pm 110$

1490 B.c.

$3290 \pm 100$

1340 B.C.

\section{Alice Springs series}

Material from late Quaternary piedmont sediments and paleosols in Alice Springs region, N Territory. Coll. 1969 and subm. by G. E. Williams, Univ. of Adelaide. Comment (G.E.W.): carbonate samples rinsed in dilute $\mathrm{HCl}$ prior to submission for dating. 
N-686. Jessie Creek

3350 в.c.

Charcoal from moderately consolidated red sand, $1.7 \mathrm{~m}$ below top of bluff, W side of Jessie Creek, ca. $300 \mathrm{~m} \mathrm{~S}$ of Jessie Gap $\left(23^{\circ} 45^{\prime} \mathrm{S}\right.$ Lat, $134^{\circ} 1^{\prime}$ E Long).

\section{N-687. Undoolya 1}

Modern

Charcoal from poorly consolidated red sand and gravel, 15 to $20 \mathrm{~cm}$ below top of bluff $2.5 \mathrm{~m}$ high, midfan area of small fan $11 \mathrm{~km} \mathrm{E}$ of Undoolya Gap (23 $45^{\prime}$ S Lat, $134^{\circ} 13^{\prime}$ E Long).

\section{N-689. Undoolya 2}

$565 \pm 100$

Charcoal from moderately consolidated red sand, $1.35 \mathrm{~m}$ below top of bluff and directly below N-687.

\section{N-688. Undoolya 3}

A.D. 1160

$790 \pm 100$

Charcoal from red sand and silt, $80 \mathrm{~cm}$ below top of terrace within main gully near apex of same fan $\left(23^{\circ} 44^{\prime} \mathrm{S}\right.$ Lat, $134^{\circ} 13^{\prime} \mathrm{E}$ Long).

\section{N-691. Undoolya 4}

$1570 \pm 105$

Charcoal from prismatic red silt and fine sand, 1.2 to $3 \mathrm{~m}$ below top of vertical bluff at apex of same fan $\left(23^{\circ} 44^{\prime} \mathrm{S}\right.$ Lat, $134^{\circ} 13^{\prime} \mathrm{E}$ Long).

\section{N-690. Williams Creek 1}

$1220 \pm 100$

Charcoal from moderately consolidated red sand, 1 to $2 \mathrm{~m}$ below top of bluff on $\mathrm{N}$ side of Williams Creek near junction with Todd R. (23 $48^{\prime}$ S Lat, $134^{\circ} 19^{\prime}$ E Long).

\section{N-693. Williams Creek 2}

Nodules of pedogenic carbonate from prismatic red silt ca. $2.5 \mathrm{~m}$ below top of bluff on E side of Williams Creek, just S of Alice SpringsAllua Well rd. (23 $48^{\prime}$ S Lat, $134^{\circ} 19^{\prime}$ E Long).

N-692. Twin Bore

$12,100 \pm 200$

Nodules and cylindroids of pedogenic carbonate from prismatic red sand $2.5 \mathrm{~m}$ below top of bluff on $\mathrm{S}$ side of gully, $8 \mathrm{~km} \mathrm{~S}$ of Twin Bore

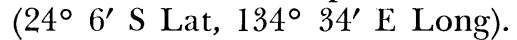

\section{N-694. Allua Well}

$18,600 \pm 360$

Massive authigenic carbonate ("ground-water calcrete") from prismatic red silt $2.5 \mathrm{~m}$ below top of bluff on $\mathrm{S}$ side of gully, $100 \mathrm{~m} \mathrm{~S}$ of Allua Well (23 $46^{\prime} \mathrm{S}$ Lat, $134^{\circ} 44^{\prime}$ E Long).

\section{N-695. Jessie Gap} $25,300 \pm 750$

Nodules of pedogenic carbonate from blocky red clay $1.5 \mathrm{~m}$ below 
top of road cut at base of alluvial cone, ca. $400 \mathrm{~m} \mathrm{E}$ of Jessie Gap (23 $45^{\prime}$ S Lat, $134^{\circ} 1^{\prime}$ E Long).

\section{N-730. Sellicks Hill}

$7510 \pm 150$

5560 в.c.

Charcoal from consolidated gray sand 2.6 to $2.8 \mathrm{~m}$ below top of alluvial terrace (Waldeila Formation, Ward, 1966), gully sec. W of Sellicks Hill, ca. $55 \mathrm{~km} \mathrm{~S}$ of Adelaide, S Australia $\left(35^{\circ} 20^{\prime} \mathrm{S}\right.$ Lat, $138^{\circ}$ 28' E Long). Coll. 1969 and subm. by G. E. Williams.

\section{Ocean Grove series}

Material from coastal dune and foreshore, ca. $4 \mathrm{~km} \mathrm{E}$ of Ocean Grove, Victoria (38 $18^{\prime} \mathrm{S}$ Lat, $144^{\circ} 34^{\prime}$ E Long). Coll. 1970 and subm. by G. E. Williams.

\section{N-831. Ocean Grove 1}

$5780 \pm 140$

Charcoal from older gray loam horizon in coastal dune, ca. $11 \mathrm{~m}$ above high-water line.

\section{N-832. Ocean Grove 2}

Charcoal from younger gray loam horizon in coastal dune, ca. $11 \mathrm{~m}$ above high-water line.

N-833. Ocean Grove 3

$124 \pm 1.5 \%$ of modern

Modern shells of marine gastropod (Subninella undulata) from rock pools on foreshore. Comment: high $\mathrm{C}^{14}$ content attributed to hydrogen bomb effect.

\section{N-834. Ocean Grove 4}

Shells from younger gray loam horizon, assoc. with N-832. Comment (G.E.W.): outer $20 \%$ of material removed by $\mathrm{HCl}$ treatment.

\section{N-835. Ocean Grove 5}

$14,900 \pm 280$ 12,950 в.C.

Shell fragments from beach rock of sandstone and conglomerate on foreshore. Comment (G.E.W.): outer 20\% of material removed by $\mathrm{HCl}$ treatment. This date, for material from indurated shore deposits near modern sea level, is incompatible with chronology of late Wisconsin sea levels. The material has probably recrystallized; the date is minimum for the beach rock.

\section{N-781. San Miguel Island}

\section{United States}

Pismo clam (Tivela stultorum) from surface at old beach terrace, ca. $85 \mathrm{~m}$ above mean sea level, San Miguel I., California $\left(34^{\circ} 2^{\prime} \mathrm{N}\right.$ Lat, $120^{\circ} 25^{\prime} \mathrm{W}$ Long). Coll. 1969 and subm. by D. L. Johnson, Univ. of Illinois. Comment (D.L.J.): concentration of pismo clams on upper terrace of $\mathrm{W}$ end of island near Judith Rock indicates former sandy 
bottom, suggesting, with other evidence, existence of former strait which bisected island in $\mathrm{W}$ to SE direction (Johnson, 1971).

\section{Great Britain}

\section{N-798. Sand Hutton}

\section{A.D. 1150}

$800 \pm 100$

Charcoal from 83 to $90 \mathrm{~cm}$ below surface at Scrogs Wood, Sand Hutton, Yorkshire (54 $4^{\circ} 1^{\prime} \mathrm{N}$ Lat, $0^{\circ} 56^{\prime} \mathrm{W}$ Long). Coll. 1968 and subm. by B. Matthews, Soil Survey of England and Wales. Comment (B.M.): sample was anticipated to relate to Neolithic forest clearance. Date suggests, however, that it results from medieval burning and that ca. 80 $\mathrm{cm}$ of eolian sand and colluvium has accumulated near base of York moraine in $800 \mathrm{yr}$, burying former Podzol.

\section{N-820. East Moor}

$9950 \pm 180$ 8000 B.C.

Organic material (gyttja) in eolian sand from 94 to $95.5 \mathrm{~cm}$ below surface, East Moor, Sutton-on-the-Forest, Yorkshire $\left(54^{\circ} 4^{\prime} \mathrm{N}\right.$ Lat, $1^{\circ}$ $4^{\prime}$ W Long). Coll. 1969 and subm. by B. Matthews. Comment (B.M.): this and N-488 (10,700 \pm 190 , R., 1969, v. 11, p. 455) provide limiting dates for deposition of eolian sand in Vale of York (Matthews, 1970).

\section{N-810. Doncaster}

$11,100 \pm 200$

Organic material from peaty layer over lacustrine silt, overlain by $22 \mathrm{~cm}$ silt and $43 \mathrm{~cm}$ sand, $8 \mathrm{~km} \mathrm{NE}$ of Doncaster, England $\left(53^{\circ} 33^{\prime}\right.$ $\mathrm{N}$ Lat, $1^{\circ} 1^{\prime} \mathrm{W}$ Long). Coll. 1968 and subm. by R. A. Jarvis, Soil Survey of England and Wales.

\section{E. Africa}

Late Quaternary stratigraphy and archaeology in E Africa

In $S$ part of Lake Nakuru basin in Kenya, 3 stratigraphic units, each separated by disconformities, have been given interim designations as formations "A", "B", and " $\mathrm{C}$ " (oldest to youngest). "Formation A" is Upper Pleistocene (see date I-5062-64); "Formation B" consists largely of deposits relating to most recent episode in which Lake Nakuru filled up to its outlet level (ca. $+20.88 \mathrm{~m}$ ) and is terminal Pleistocene and early Holocene (Washbourn 1967, 1970). "Formation C" includes evidence of a mid-Holocene minor high stand. Sample N-821 relates to age of "Formation C" while N-822 (1-3) were drawn from base of "Formation B".

Lake Magadi is ringed by a discontinuous terrace of sediments evidently deposited during a higher-water phase (Baker, 1958). Sample N-862 dates one horizon in these beds.

N-821. Prolonged Drift (GrJi 1)

$3640 \pm 120$

1690 B.C.

Charcoal from a horizon (brush fire?) in brown alluvial silt that directly overlies diatomaceous silt of mid-Holocene high stand of Lake 
Nakuru. Pottery occurs on charcoal horizon and rich "Kenya Wilton" industry with stone bowls and edge-ground axe is stratified in silt above $\left(0^{\circ} 29^{\prime} \mathrm{S}\right.$ Lat, $36^{\circ} 6^{\prime} \mathrm{E}$ Long). Coll. 1969 and subm. by G. L. Isaac and C. M. Nelson, Univ. of California, Berkeley.

\section{Enderit Drift series (GsJi 2/T)}

Charcoal from archaeologic occurrence dominated by delicate awls, backed blades, and burins. Charcoal and artifacts were recovered by excavation into consolidated lens of colluvium stratified at base of "Formation B" at alt. ca $2088 \mathrm{~m}$, i.e., $67.06 \mathrm{~m}$ above modern lake. The strata document a transgressive phase in lake fluctuation $\left(0^{\circ} 31^{\prime}\right.$ S Lat, 36 $6^{\prime}$ E Long). Coll. 1969 and subm. by G. L. Isaac and H. V. Merrick.

\section{N-822-1. Enderit Drift 1 (No. 190)}

$12,300 \pm 220$

N-822-2. Enderit Drift 2 (No. 177)

N-822-3. Enderit Drift 3 (No. 195)

10,350 в.C.

$12,200 \pm 220$ 10,250 в.C.

$12,000 \pm 220$ 10,050 B.C.

\section{N-862. Lake Magadi}

$9120 \pm 180$ 7170 в.c.

Organic fraction of a highly carbonaceous, fish-fossil lamina in High Magadi Beds at "Dry Lagoon" ( $1^{\circ} 59^{\prime} \mathrm{S}$ Lat, $36^{\circ} 6^{\prime}$ E Long). Coll. 1969 and subm. by G. L. Isaac.

\section{PEDOLOGIC SAMPLES}

Total organic carbon of humic horizon in volcanic ash soil from various localities, coll. 1970 by Y. Yamada, Natl. Inst. Agric. Sci., and dated to determine relationship between soil age and properties of humus in soil.

\section{Nakanohara series}

Sample from various depths in volcanic ash beds at Nakanohara,

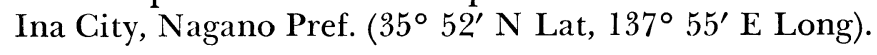

N-844. Ina 1

$810 \pm 105$

From depth 0 to $14 \mathrm{~cm}, \mathrm{~A}_{\mathrm{p}}$ horizon. Carbon content: $10.55 \%$.

N-845. Ina 2

$1850 \pm 110$

From depth 14 to $23 \mathrm{~cm}, \mathrm{~A}_{12}$ horizon. Carbon content: $9.63 \%$.

N-846. Ina 3

$\mathbf{3 9 3 0} \pm \mathbf{1 3 0}$

1980 B.c.

From depth 23 to $48 \mathrm{~cm}$, IIA horizon. Carbon content: $8.29 \%$. 
N-847. Ina 4

$6920 \pm 150$

From depth 48 to $80 \mathrm{~cm}$, IIIA horizon, Carbon content: $3.69 \%$.

N-848. Ogurohara

$1270 \pm 105$

A.D. 680

From $A_{11}$ horizon, depth 0 to $22 \mathrm{~cm}$, at Ogurohara, Ina City, Nagano Pref. (35 $50^{\prime} \mathrm{N}$ Lat, $137^{\circ} 55^{\prime} \mathrm{E}$ Long). Carbon content: $13.45 \%$.

\section{N-910. Minami Rokuroshi}

$4910 \pm 130$

2960 B.c.

From $A_{12}$ horizon, depth 13 to $37 \mathrm{~cm}$, at Minami Rokuroshi, Ono City, Fukui Pref. (36 $1^{\prime}$ N Lat, $136^{\circ} 34^{\prime}$ E Long). Carbon content: $9.58 \%$.

\section{ARCHAEOLOGIC SAMPLES}

\section{Irie series}

$$
\text { A. Japan }
$$

Fossil animal bone from Irie, Abuta-gun, Hokkaido $\left(42^{\circ} 34^{\prime} \mathrm{N}\right.$ Lat, $140^{\circ} 45^{\prime}$ E Long). Coll. 1966 and subm. by N. Shimoda, Muroran Inst. of Technol. Comment: collagen fraction dated. Dates serve to test possibility of dating bones by measurements of their manganese content (Shimoda, 1971a, 1971b).

N-680. Irie 1

N-681. Irie 2

Both samples are from same shell bed.

\section{N-682. Ponnai, Muroran}

Fossil animal bone from Ponnai, Motowanishi, Muroran City, Hokkaido $\left(40^{\circ} 20^{\prime} \mathrm{N}\right.$ Lat, $140^{\circ} 0^{\prime} \mathrm{E}$ Long). Assoc. with pottery of Early Jomon (Ento-Kaso type) to Middle Jomon (Ento-Joso type) periods.

\section{Snyder site series}

\section{B. United States and Canada}

Charcoal from Snyder site, N of El Dorado, Butler Co., Kansas

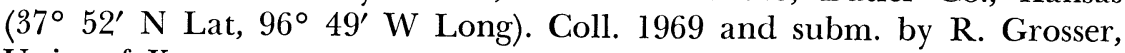
Univ. of Kansas.

N-769. Snyder Site 1

$1970 \pm 110$

20 B.c.

From 40 to $55 \mathrm{~cm}$ below surface. Assoc. with Archaic remains.

N-770. Snyder Site 2

$3650 \pm 140$

From 100 to $125 \mathrm{~cm}$ below surface. Assoc. with Archaic rema 
N-771. Snyder Site 3

From 125 to $140 \mathrm{~cm}$ below surface. Assoc. with Archaic remains.

\section{Kisameet series}

Charcoal from shell midden in Kisameet, British Columbia, Canada $\left(51^{\circ} 58^{\prime} \mathrm{N}\right.$ Lat, $127^{\circ} 53^{\prime} \mathrm{W}$ Long). Coll. 1969 by Terja Birkedal; subm. by R. Luebbers, Univ. of Colorado.

\section{N-788. Kisameet 1 (FS2.10B.1)}

$1810 \pm 100$

From midpoint of site, $1.5 \mathrm{~m}$ below surface.

\section{A.D. 140}

$$
2290 \pm 110
$$

340 B.C.

N-789. Kisameet 2 (FS2.17C.1)

From hearth near basement gravels, $2.55 \mathrm{~m}$ below surface, $15 \mathrm{~cm}$ above gravel.

\section{Cerro Chacaltepec series}

$$
\text { C. Mexico }
$$

Charcoal from site at Cerro Chacaltepec, Tlaltizapan, Morelos, Mexico (18 $40^{\prime} \mathrm{N}$ Lat, 99 $7^{\circ} \mathrm{W}$ Long). Coll. 1967 and subm. by D. C. Grove, Univ. of Illinois at Urbana-Champaign (Grove, 1968).

\section{N-816. Cerro Chacaltepec 1}

$2640 \pm 120$

From level 260 to $280 \mathrm{~cm}$ below surface, marking stratigraphic transition from Olmec to Middle Preclassic styles.

\section{N-817. Cerro Chacaltepec 2}

From level 300 to $320 \mathrm{~cm}$ below surface, marking an apparent period of Olmec influence.

\section{N-818. San Pablo}

$2920 \pm 160$

Charcoal from levels yielding Olmec ceramics at San Pablo, Morelos,

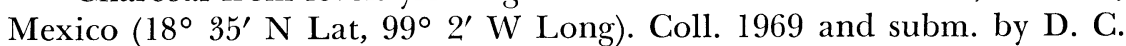
Grove.

$$
\text { D. Africa }
$$

\section{N-869. Hidden Valley, Adrar Bous}

$$
\begin{aligned}
& 4440 \pm 120 \\
& 2490 \text { B.c. }
\end{aligned}
$$

Charcoal from hearth assoc. with Burial 1, beneath tumulus at Hidden Valley, Adrar Bous, Republic of Niger $\left(20^{\circ} 19^{\prime} \mathrm{N}\right.$ Lat, $8^{\circ} 57^{\prime}$ $\mathrm{E}$ Long). Hearth situated ca. $.61 \mathrm{~m}$ below base of cairn and former ground surface and $.3 \mathrm{~m}$ above and immediately NE of burial. Coll. 1970 and subm. by J. D. Clark, Univ. of California, Berkeley. Comment (J.D.C.): estimated age: Pre-Islamic (Libyco-Berber). Chouchet-type cairn in which this burial occurred is usually considered to date to LibycoBerber times. That at El Barkat, W Fezzan $\left(24^{\circ} 52^{\prime} \mathrm{N}\right.$ Lat, $10^{\circ} 23^{\prime}$ E Long) was dated to $1300 \pm 120 \mathrm{yr}, 510-750$ A.D.) N-869 appears too 
old for burial itself. Presumably, it dates wood used for probable funeral fire.

N-870. North East Valley, Adrar Bous

$4910 \pm 140$

Fine charcoal fragments from saucer-shaped hollow beneath concentration of broken and burned animal bones, food waste from a single meal, Area 5, North East Valley, Adrar Bous $\left(20^{\circ} 19^{\prime} \mathrm{N}\right.$ Lat, $8^{\circ} 57^{\prime}$ E Long). Coll. 1970 and subm. by J. D. Clark. Comment (J.D.C.): estimate age: Tenerian Neolithic. Date agrees with estimated age for Tenerian 3500 to 2500 B.c.

\section{N-871. Temet Wadi, Graboun}

A.D. 1430

$520 \pm 100$

Charcoal from hearth at base of dune overlying main terrace deposits at Temet Wadi, ca. $2.4 \mathrm{~km} \mathrm{NE}$ of T-junction, Graboun, Aïr Mts., Republic of Niger (20 $2^{\circ}$ N Lat, $8^{\circ} 32^{\prime}$ E Long). Coll. 1970 and subm. by J. D. Clark. Comment (J.D.C.): localities at Graboun yielded unspecialized lithic industry, grindstones and sherds of decorated Neolithic and undecorated wares, the latter probably final or post-Neolithic. Although no artifacts were in direct assoc. with hearth, association was thought possible. Result disproves this, except, possibly, for some undecorated pottery.

\section{Bornu series}

Charcoal from Bornu site, NE Nigeria $\left(11^{\circ} 32^{\prime} \mathrm{N}\right.$ Lat, $13^{\circ} 40^{\prime} \mathrm{E}$ Long). Coll. 1969 and subm. by G. E. Connah.

N-793. Bornu 1 (UI 703)

$3830 \pm 250$

From Spit 14, Cutting I.

N-794. Bornu 2 (UI 704) 1880 B.C.

From Spits 11 and 12, Cutting I.

$$
2960 \pm 160
$$
1010 в.c.

N-795. Bornu 3 (UI 705)

From Spit 12, Cutting II.

\section{N-796. Bornu 4 (UI 706)}

From Spits 7, 8, 9 and 10, Cutting II.

\section{Baha mound series}

Charcoal from Site HK.68.4, Tr. 1, Sq. 1, Baha mound, Nigeria $\left(10^{\circ} 50^{\prime} \mathrm{N}\right.$ Lat, $4^{\circ} 46^{\prime} \mathrm{E}$ Long). Coll. 1968 by D. P. Hartle; subm. by T. Shaw, Univ. of Ibadan.

N-824. Baha Mound 1 (UI 707)

$2080 \pm 105$

From depth 460 to $480 \mathrm{~cm}$. 
N-825. Baha Mound 2 (UI 708)

From depth 340 to $360 \mathrm{~cm}$.

N-826. Baha Mound 3 (UI 709)

From depth 320 to $340 \mathrm{~cm}$.

N-827. Baha Mound 4 (UI 7010)

From depth 200 to $220 \mathrm{~cm}$.

N-828. Baha Mound 5 (UI 7013)

From depth 100 to $120 \mathrm{~cm}$.
$1050 \pm 125$

A.D. 900

$1150 \pm 140$

A.D. 800

$1170 \pm 120$

A.D. 780

$1010 \pm 110$

A.D. 940

\section{Leopard's Kopje Main Kraal site series}

Sample from Leopard's Kopje Main Kraal site, Rhodesia $\left(20^{\circ} 7^{\prime}\right.$ S Lat, $28^{\circ} 26^{\prime}$ E Long). Coll. 1969 by T. N. Huffman, Univ. of Illinois; subm. by B. M. Fagan, Univ. of California, Santa Barbara.

\section{N-772. Leopard's Kopje Main Kraal Site 1}

$$
1050 \pm 100
$$

Carbonized seeds incl. sorghum, cowpeas, and groundnuts, as well as wild seeds from storage hut.

\section{N-773. Leopard's Kopje Main Kraal Site 2 A.D. 1825}

$125 \pm 100$

Charcoal from recent occupation of site.

\section{Mutobo series}

Charcoal from $1.2 \mathrm{~m}$ below surface at Iron age mound at Kalomo, S Prov. Zambia (17 ${ }^{\circ} 2^{\prime} \mathrm{S}$ Lat, $26^{\circ} 21^{\prime}$ E Long). Assoc. with Kalomotype occupation. Coll. 1968 and subm. by B. M. Fagan.

\section{N-596. Mutobo $1(\mathrm{MU} / \mathrm{RC} / 01)$}

\section{N-597. Mutobo 2 (MU/RC/02)}

$$
1030 \pm 110
$$
A.D. 920

$$
1120 \pm 110
$$

A.D. 830

Comment (B.M.F.): samples are from same cultural level, and agree well with dates obtained from other Kalomo mounds.

\section{Makwe series}

Charcoal from Makwe rock shelter of Late Stone age, Katete dist., Zambia (14 $24^{\prime} \mathrm{S}$ Lat, $31^{\circ} 56^{\prime} \mathrm{E}$ Long). Coll. 1966 by D. W. Phillipson; subm. by B. M. Fagan.

N-903. Makwe 1

From 76 to $79 \mathrm{~cm}$ below surface of Sq. c-12, Horizon 3 ii. 
N-904. Makwe 2

$4920 \pm 130$

2970 B.c.

From Sq. c-13, Level 12, Horizon 3ii. Comment (D.W.P.): dates agree well with others from same site (GX-1553; SR-205; GX-1554; SR204 and GX-1555) and date main Late Stone age occupation of Makwe rock shelter.

\section{Thandwe series}

Charcoal from Thandwe rock shelter of Late Stone age and Iron age, Chipata dist., Zambia (13 ${ }^{\circ} 49^{\prime} \mathrm{S}$ Lat, $32^{\circ} 28^{\prime} \mathrm{E}$ Long). Coll. 1970 by D. W. Phillipson; subm. by B. M. Fagan.

\section{N-905. Thandwe 1}

From Sq. G, Layer 5.

N-906. Thandwe 2

From Sq. F-G, Layer 6.

\section{N-907. Thandwe 3}

From Sq. D-E, Layer 7. Comment (D.W.P.): an internally consistent series. N-905 and N-906 date 1st appearance of Early Iron age pottery at Thandwe: dates are somewhat later than those for same phenomenon elsewhere in E Zambia, but are supported by evolved typology of pottery. N-907 dates 2 human burials assoc. with a Late Stone age industry.

\section{N-908. Kamnama}

$1600 \pm 110$

Charcoal from Kamnama site of Early Iron age, Chipata dist., Zambia (13० 32' S Lat, 32 $51^{\prime}$ E Long), from Tr. V, Layer 2. Coll. 1970 by D. W. Phillipson; subm. by B. M. Fagan. Comment (D.W.P.): dates a large (5 ha.) Early Iron age village site on the Luangwa-Lake Malawi watershed. Early date is supported by similarity between the Kamnama pottery and that of contemporary earliest Iron age in Malawi.

\section{Simbusenga series}

Charcoal from stratified Iron age village midden at Simbusenga, Zambia (17 $35^{\prime} \mathrm{S}$ Lat, $25^{\circ} 35^{\prime} \mathrm{E}$ Long). Total midden accumulation averages $1.68 \mathrm{~m}$. Mound contains 7 village horizons. Basal horizon assoc. with Kumadzulo-type ceramics above which are horizons affiliated with Kamangoza and Sekute phase of Kalomo tradition and typical Simbusenga pottery-bearing horizons related to Sinde, Simonga, and Mukuni sites. Coll. 1969 and subm. by J. O. Vogel, Livingstone Mus. Samples are divided into 5 groups.

\section{Group I}

N-731. Simbusenga 1

15 to $30 \mathrm{~cm}$ below surface.
Modern 
$365 \pm 105$

N-732. Simbusenga 2 A.D. 1585

15 to $30 \mathrm{~cm}$ below surface.

$395 \pm 105$

\section{N-733. Simbusenga 3}

A.D. 1555

15 to $30 \mathrm{~cm}$ below surface.

Samples assoc. with Village Horizon G, uppermost stratigraphically defined occupation level. Comment (J.O.V.): should date latest occupation of midden.

\section{Group II}

N-734. Simbusenga 4

$167 \mathrm{~cm}$ below surface.

\section{N-735. Simbusenga 5}

$167 \mathrm{~cm}$ below surface.

Samples recovered from pits, containing pottery of Early Iron age type and located in sterile Kalahari sand at base of mound. Comment (J.O.V.): should date earliest occupation of Simbusenga midden.

\section{Group III}

N-736. Simbusenga 6

Modern

$51 \mathrm{~cm}$ below surface, charred hut pole assoc. with Village Horizon G.

\section{Group IV}

\section{N-737. Simbusenga 7}

$61 \mathrm{~cm}$ below surface.

N-738. Simbusenga 8

$76 \mathrm{~cm}$ below surface.

N-739. Simbusenga 9

$91 \mathrm{~cm}$ below surface.

N-740. Simbusenga 10

$107 \mathrm{~cm}$ below surface.

N-741. Simbusenga 11

$122 \mathrm{~cm}$ below surface.

N-742. Simbusenga 12

$137 \mathrm{~cm}$ below surface.
A.D. 1270

$1170 \pm 105$

A.D. 780

$680 \pm 105$ 


\section{N-743. Simbusenga 13}

A.D. 1030

$1.5 \mathrm{~m}$ below surface.

Series of samples from various localities within site combined to form a stratified collection. Comment (J.O.V.): date village Horizons B through F. N-743 dates same assocs. as Group II.

\section{Group V}

N-744. Simbusenga 14

$46 \mathrm{~cm}$ below surface.

N-745. Simbusenga 15

$61 \mathrm{~cm}$ below surface.

N-746. Simbusenga 16

$76 \mathrm{~cm}$ below surface.

N-747. Simbusenga 17

$91 \mathrm{~cm}$ below surface.

\section{N-748. Simbusenga 18}

$1.1 \mathrm{~m}$ below surface.

Series of samples duplicating part of Group IV. Comment (J.O.V.): $\mathrm{N}-744$ dates same assocs. as Group III.

General Comment (J.O.V.): dated samples form 5 very distinct groups. Group A, 8th century date assoc. with Early Iron age pit (N-735). Group $\mathrm{B}$, predominantly 10 to 11 th century occupation of site (N-746, N-739, N-740, N-748, N-741, N-742, N-743). Group C, predominantly 13th century occupation of site (N-734, N-747, N-745, N-744 and N-741) and later Group D of predominantly 16th century provenance $(\mathrm{N}-732, \mathrm{~N}-733$, $\mathrm{N}-737, \mathrm{~N}-738$ ). Two modern dates (N-731, N-736) represent very latest Leya occupation. A rank correlation analysis of chronologic ranking with stratigraphic order of sample means shows a highly significant correlation and dated sequence is probably reasonable indication of occupation chronology at Simbusenga. There were 7 village horizons in Simbusenga deposit. The earliest is typologically compatible with 8th century date. A short hiatus separates this occupation from Kalomo tradition assoc. ones of Group B dates. These agree well with known dates from Kalomo tradition materials. Remaining groups date distinctive Simbusenga series of ceramics and agree with series from Sinde, Mukuni, and Simonga.

\section{Shilma series}

Charcoal from site at Shilma, N.E. Nigeria $\left(11^{\circ} 55^{\prime} \mathrm{N}\right.$ Lat, $14^{\circ} 21^{\prime}$ E Long). Coll. 1969 and subm. by G. E. Connah, Univ. of Ibadan. 
N-791. Shilma 1 (UI 701)

From Cutting I, Spit 3.

N-792. Shilma 2 (UI 702)

730 в.с.

From Cutting II, Spit 2.

\section{Narosura series}

Samples from various depth from surface at Narosura, Narok dist., Kenya $\left(1^{\circ} 32^{\prime} \mathrm{S}\right.$ Lat, $35^{\circ} 50^{\prime} \mathrm{E}$ Long), assoc. with obsidian industry, pottery, stone bowls, stone axe, and bones mostly of domesticated animals. N-496 coll. 1968 by B. Golden, remainder coll. 1969 by K. Odner; subm. by R. C. Soper, Brit. Inst. Hist. Archaeol., E. Africa.

N-496. Narosura, bone

$2260 \pm 110$

310 B.c.

Animal bone fragments, 30 to $80 \mathrm{~cm}$ below surface. Comment: collagen fraction dated.

N-700. Narosura 1 (E12/E14)

$2360 \pm 110$

Charcoal from $30 \mathrm{~cm}$ below surface.

410 B.c.

N-701. Narosura 2 (F16)

$2660 \pm 120$

Charcoal from 50 to $70 \mathrm{~cm}$ below surface.

N-702. Narosura 3 (F16)

$2760 \pm 120$

Charcoal from 70 to $80 \mathrm{~cm}$ below surface.

N-703. Narosura 4 (E17)

$2640 \pm 120$

Charcoal from 80 to $90 \mathrm{~cm}$ below surface.

690 B.C.

\section{N-784. Chobi}

$1660 \pm 130$

A.D. 290

Charcoal from 28 to $38 \mathrm{~cm}$ below surface in lower part of potterybearing horizon on open site ca. $1 \mathrm{~km} \mathrm{~N}$ of Victoria Nile in Chobi Sec., Murchison Falls Natl. Park, Uganda $\left(2^{\circ} 15^{\prime} \mathrm{N}\right.$ Lat, $32^{\circ} 12^{\prime}$ E Long). Assoc. with quartz flakes and pottery incl. both Urewe ("Dimple-based") ware and "Boudiné ware" in close assoc. Coll. 1968 and subm. by R. C. Soper.

\section{N-787. Luluampembele (F16)}

Charcoal from 50 to $60 \mathrm{~cm}$ below surface at Luluampembele, Iramba dist., Tanzania $\left(4^{\circ} 23^{\prime} \mathrm{S}\right.$ Lat, $34^{\circ} 24^{\prime} \mathrm{E}$ Long), from Late Stone age rock shelter, below rock wall with paintings at alt. $1432 \mathrm{~m}$. Finds include quartz, animal bone, ostrich egg shell beads. Coll. and subm. 1970 by K. Odner. 


\section{Kilimanjaro region series}

Charcoal from various sites in Kilimanjaro region, Tanzania. Coll. and subm. 1970 by K. Odner.

\section{N-882. Marangu Teacher's College}

$725 \pm 180$

Charcoal from Marangu Teacher's College site at alt $1463 \mathrm{~m}$, Marangu, E Vunjo ( $3^{\circ} 17^{\prime} \mathrm{S}$ Lat, $37^{\circ} 31^{\prime} \mathrm{E}$ Long). Assoc. with unknown pottery.

\section{N-883. Mwika}

$1700 \pm 330$

Charcoal from Mwika site at alt. $1509 \mathrm{~m}$, Mwika, E Vunjo $\left(3^{\circ} 16^{\prime}\right.$ $S$ Lat, $37^{\circ} 35^{\prime}$ E Long). Assoc. with pottery of Kwale and Maore ware.

\section{N-884. Old Moshi}

$2200 \pm 430$

Charcoal from Old Moshi site at alt. $991 \mathrm{~m}$, E Hai $\left(3^{\circ} 19^{\prime} \mathrm{S}\right.$ Lat, $37^{\circ} 24^{\circ} \mathrm{E}$ Long). Assoc. with pottery probably developed from Maore ware.

\section{N-885. Matunda}

$510 \pm 190$

Charcoal from Matunda site at alt. $914 \mathrm{~m}$, Central Hai $\left(3^{\circ} 20^{\prime} \mathrm{s}\right.$ Lat, $37^{\circ} 17^{\prime} \mathrm{E}$ Long). Assoc. with pottery seemingly connected with N-884.

\section{Lothagam Hill series}

Samples from sites within $24.2 \mathrm{~km}$ area near Lothagam Hill, ca. 11.3 to $16 \mathrm{~km} \mathrm{~W}$ of Lake Rudolf, Turkana dist., $\mathrm{N}$ Kenya $\left(2^{\circ} \mathrm{N}\right.$ Lat, $36^{\circ}$ E Long). Coll. 1969 and subm. by L. H. Robbins, Michigan State Univ.

N-812. Lothagam Hill 1 ( $\mathrm{Zu}-10)$

$6200 \pm 130$

Charcoal from scattered stain, 10 to $20 \mathrm{~cm}$ below surface, in compact sand. Assoc. with cultural remains of E African Late Stone age.

\section{N-813. Lothagam Hill 2 ( Zu-6)}

$7960 \pm 140$

Shell from shell bed, $35 \mathrm{~cm}$ below surface, in grayish-white sandy clay of lake beds of Holocene Lake Rudolf. Site is of Late Stone age assoc. with 2 types of decorated pottery.

\section{N-814. Lothagam Hill 3 (Bb-14)}

$5020 \pm 220$

Burned clay? eroding out in situ from brown sandy-clay like deposit, 10 to $12 \mathrm{~cm}$ below surface. Assoc. with several types of pottery as well as Late Stone Age artifacts.

General Comment (L.H.R.): N-813 dates high beach level and agrees very well with UCLA date $(7560 \pm 1000$, UCLA-1247E, R., 1968, v. 10, p. 402) from shell sample for same high lake stage nearby. Decorated 
pottery incorporated in deposits is oldest for $\mathrm{E}$ Africa. N-812 seems to date cultural activity on site assoc. with old lake. Pottery assoc. with $\mathrm{N}-814$ is different from either of above sites and the site is located at higher elev.

\section{Rangi site series}

Samples from Rangi site of Late Stone/Iron age on slopes of Kadam Mt., Karamoja dist., E Uganda ( $1^{\circ} 48^{\prime} \mathrm{N}$ Lat, 34 $48^{\prime} \mathrm{E}$ Long). Coll. 1970 and subm. by L. H. Robbins.

N-815. Rangi, Bone 1

Modern

Burned bone from rock shelter, 160 to $180 \mathrm{~cm}$ below surface, in brown soil containing broken and decayed bedrock originating from shelter. Artifacts include microliths, pottery, and ground stone.

\section{N-863. Rangi, Bone 2}

$510 \pm 105$

Bone fragments from gray brown soil very rich with decorated pottery, chipped stone, and iron artifacts.

\section{N-864. Rangi, charcoal}

\section{A.D. 1660}

Charcoal from lower level.

General Comment (L.H.R.): date of N-863 is quite reasonable. Younger date of N-864 might be due to contamination. Modern date of N-815 is probably due to collecting error.

\section{N-865. Kaupokwalot cave}

$330 \pm 105$

Charcoal from Kaupokwalot cave, $8 \mathrm{~km} \mathrm{~S}$ of Rangi site $\left(2^{\circ} 52^{\prime}\right.$ $\mathrm{N}$ Lat, $35^{\circ} 18^{\prime} \mathrm{E}$ Long), from burned zone underlying $20 \mathrm{~cm}$ of soft powdery soil with high content of decomposed bat guano. Coll. 1970 and subm. by L. H. Robbins. Assoc. with highly weathered iron blade fragments.

\section{REFERENCES}

Baker, B. H., 1958, Geological Survey of Kenya, Rept. 42.

Grove, D. C., 1968, The Morelos Preclassic and the Highland Olmec problem: an archaeological study: Doctoral dissert., Univ. of California at Los Angeles.

Johnson, D. L., 1971, Geomorphology and paleopedology of San Miguel Island, California: Ph.D. thesis, Univ. of Kansas, Lawrence, Kansas.

Mathews, B., 1970, Age and origin of Aeolian sand in the Vale of York: Nature, v. 227, p. 1234-1236.

Shimoda, N., 1971a, On the relation between the manganese content and the age of the bones from Irie site, Abuta-gun, Hokkaido: Hokkaido Archaeology, v. 7, p. $17-30$

Tech. Rept. Muroran Inst. Technol., v. 7, p. 99-108.

Ward, W. T., 1966, Geology, geomorphology, and soils of the southwestern part of County Adelaide, South Australia: C.S.I.R.O. Soil Pub., no. 23, p. 115.

Washbourn, C. K., 1967, Lake levels and Quaternary climates in the Eastern Rift Valley of Kenya: Nature, v. 216, p. 672-673.

Washbourn-Kamau, C. K., 1970, Late Quaternary chronology of the Nakuru-Elementeita Basin, Kenya: Nature, v. 226, p. 253-254. 